\title{
BODY CONDITION OF MALE FARM MINK (Neovison vison) DURING A MATING SEASON
}

\section{KONDYCJA SAMCÓW NORKI HODOWLANEJ (Neovison vison) W OKRESIE OKOŁOKOPULACYJNYM}

\author{
Laboratory of Animal Anatomy, West Pomeranian University of Technology, Szczecin, Poland
}

\begin{abstract}
Streszczenie. Praca miała na celu ocenę wpływu kondycji samców norki hodowlanej (Neovison vison) w okresie kopulacyjnym na ich zachowanie oraz wyniki kojarzeń. Do badań wybrano 170 samców, odmiany perła. Przed okresem kryć podzielono samce na 3 grupy doświadczalne w zależności od ich kondycji: grupa I - norki bardzo chude, grupa II - norki chude i idealne pod względem kondycji, grupa III - norki o wyglądzie ciężkim i norki otyłe. Po zakończeniu okresu kryć przeanalizowano dane rozrodcze dotyczące: liczby dni, w których kryły samce, liczby kryć w ciągu dnia i w ciągu całego okresu kojarzeń, procentu samców, które nie kryły oraz procentu występowania zachowań agresywnych. W wyniku statystycznej analizy nie stwierdzono różnic w średniej liczbie dni kojarzeń, liczbie kryć w ciągu całego okresu ani w liczbie kryć w ciągu dnia. Kondycja samców miała istotny wpływ na zachowanie się zwierząt w okresie kojarzeń. Najwięcej zachowań agresywnych (około 16\%) wystąpiło u zwierząt z grup I i II, a więc u zwierząt o kondycji od bardzo chudej do idealnej; o połowę mniej takich zachowań zanotowano w grupie zwierząt otyłych (III) - ok. 8\%. Zupełnie inną zależność pokazało wygryzanie okrywy włosowej, ponieważ żaden samiec z grupy chudych i idealnych (II) nie wygryzał okrywy. Tylko samce bardzo chude z grupy I (2\%) i otyłe z grupy III (4,17\%) wygryzały okrywę. W grupie II zanotowano najmniejszy procent samców, które nie kryły (około 6\%), natomiast w grupach I i III zanotowano tych samców około $10 \%$.
\end{abstract}

Key words: mink, reproduction, mating, strength, aggression.

Słowa kluczowe: norka, reprodukcja, kojarzenie, kondycja, agresja.

\section{INTRODUCTION}

Excellent body condition of breeding stock animals is a key factor in terms of the reproduction success. The specificity of carnivorous fur-bearing animal farming involves very intensive, high-energy feeding during autumn, so that the animals were able to accumulate fat reserves for the winter (Canada Mink Breeders Association 2013) and were possibly largest during slaughter, which allows the producer to harvest a large pelt. Feeding a composed feed supplemented with free fat results in a maximum fatness of mink bodies during the slaughter season.

Corresponding author - Adres do korespondencji: Lidia Felska-Błaszczyk, Laboratory of Animal Anatomy, West Pomeranian University of Technology, Szczecin, Doktora Judyma 14, 71-466 Szczecin, Poland, e-mail: lidia.felska-blaszczyk@zut.edu.pl 
Following this intensive feeding, animals selected for the breeding stock must be corrected in order to regain the reproductive condition, which involves a short-term feeding with limited rations, also in terms of energy content and, primarily, using feeds containing low fat and no free fat, followed by intensive feeding with a high-energy feed just 4-5 days before the mating season onset (Tauson 1985 and 1988). Body condition also affects the animal's immunity; according to Schulte-Hostedde et al. (2012), mink of a higher condition score have a larger spleen compared to poor-condition animals.

Baekgaard et al. (2008) report that female condition during the period prior to mating is crucial for their reproductive success. Boudreau (2012) and Boudreau et al. (2014) claim that mink selection for large body sizes may lead to increased obesity in the breeding stock members and, in consequence, to poor reproduction performance, which had been previously demonstrated by Tinggaard et al. (2012); obese females produced smaller litters, compared to thinner females, despite the same number of placental scars, which prove embryonic implantations. Poor body condition of farmed female mink before breeding season, during pregnancy and post-partum predisposes them to nursing sickness (Rouvinen-Watt 2003). Hansen et al. (2012) observed that also male condition during the heat is of importance for the overall reproduction performance of mink. Andersen (2013) confirmed the effects of male body condition in mink on the subsequent season reproduction performance; males of the appropriate condition, which are not too thin and not too obese, attain the highest number of successful matings during the heat.

The aim of this study was to evaluate body condition of mink males during breeding season in relation to their behaviour and mating performance.

\section{MATERIAL AND METHODS}

The observations took place on a mink farm located in northern Poland. The studies involved 161 year-old Pearl-colour males. The animals were managed in standard 45/45/90 $\mathrm{cm}$ mink cages and fed the same feed based on chicken offal and fish by-product. A few days before mating, selected males were assessed for body condition score in 5-point scale proposed by Rouvinen-Watt and Armstrong (2002), which resulted in an assignment of each male to one of the following groups:

- group 1. Very thin - emaciated appearance with decreased muscle mass, a thin neck and a clearly V-shaped body, no body fat, stomach sunk in, visible shoulder and hip bones, ribs easily felt;

- group 2. Thin - a thin neck and a V-shaped waistline, no subcutaneous body fat, shoulder, hip bones and ribs easily felt;

- group 3. Ideal - a slender neck and a straight body shape, a slight amount of subcutaneous body fat, shoulder, hip bones and ribs easily felt;

- group 4. Heavy - a thicker neck and a pear-shaped body, ribs difficult to feel, shoulder and hip bones covered by a moderate fat layer, abdominal fat pad present;

- group 5. Obese - a thick neck with a slight brisket and a full body shape, ribs very difficult to feel, shoulder and hip bones covered by a moderate to thick fat layer, fat pad present in the abdomen and the tail, visible fat deposits in the limbs and the face. 
A week before the onset of the breeding season, the animals were distributed to three treatment groups:

- group I - by the 5-point scale, males belonging to group 1, i.e. very thin, $n=50$;

- group II - males belonging to groups 2 and 3, i.e. thin and ideal weight, $n=63$;

- group III - males belonging to groups 4 and 5 , heavy and obese, $n=48$.

The mating season lasted from 2 to 18 March, i.e. 17 days. The following reproduction parameters were analysed on the completion of the breeding period:

- number of days in mating,

- number of matings throughout the season,

- number of matings daily,

- fraction of aggressive behaviour incidents during mating,

- fraction of fur chewing incidents,

- fraction of males that failed to mate.

The notion of "aggressive behaviour" is defined as a biting attack on the female, which prevents copulation - in consequence, the mating is interrupted and the female is withdrawn from the male's cage for her safety.

The resulting data were processed statistically using the Statistica 12.0 package. The descriptive statistics involved arithmetic mean, standard deviation (SD) and coefficient of variability $(\mathrm{V} \%)$.

\section{RESULTS}

The statistical analysis did not reveal significant differences in the average number of days in mating, total number of matings in the season, or the average number of matings daily (Table 1). In relation to these traits, body condition of the males did not have a significant effect, as the results in groups were very similar.

Table 1. Mean number of days in mating, total number of matings during mating season and average daily number of matings

Tabela 1. Średnia liczba dni, w których samce kryły, liczba kryć w ciągu całego okresu kryć oraz średnia liczba kryć w ciągu dnia

\begin{tabular}{lcccc}
\hline \multicolumn{1}{c}{$\begin{array}{c}\text { Trait } \\
\text { Cecha }\end{array}$} & $\begin{array}{c}\text { Male conditio } \\
\text { Kondycja } \\
\text { samców }\end{array}$ & $\begin{array}{c}\text { Mean } \\
\text { Średnia }\end{array}$ & SD & V\% \\
\hline Days in mating & I & 10.62 & 4.62 & 43.54 \\
Liczba dni, w których samce kryły & II & 10.68 & 3.97 & 37.13 \\
\hline Total & III & 10.94 & 4.64 & 42.40 \\
Razem & & 10.74 & 4.36 & 40.57 \\
\hline Total number of matigs in season & I & 13.88 & 6.53 & 47.07 \\
Liczba kryć w ciągu całego okresu & II & 14.06 & 5.90 & 41.97 \\
\hline Total & III & 14.31 & 6.58 & 45.97 \\
Razem & & 14.08 & 6.27 & 44.53 \\
\hline Daily number fo matings & I & 1.30 & 0.17 & 12.85 \\
Liczba kryć w ciągu dnia & II & 1.30 & 0.17 & 13.43 \\
\hline Total & III & 1.29 & 0.16 & 12.65 \\
Razem & & 1.30 & 0.17 & 12.94 \\
\hline
\end{tabular}


Somehow different are results on the fraction of males that failed to copulate (Table 2) the highest percentage was found in groups I and III, i.e. in those very thin as well as among those heavy and obese (about 10\%), and the lowest in males of the optimal condition scores (about 6\%).

It seems that body condition of the males affected their behaviour in the presence of a female. Males of the best condition scores (group II) never chewed their fur, whereas the highest fraction of males showing such behaviour was found among those heavy and obese (group III, more than 4\%). If we look at the aggressive behaviours, the pattern was revesed, since most such incidents occurred among very thin and ideal condition (groups I and II, about $16 \%$ ), and a half of that in obese males of group III (about $8 \%$ ).

Table 2. Aggressive behaviours, males that failed to mate, fur chewing

Tabela 2. Zachowania agresywne, samce, które nie kryły samic, wygryzienia okrywy włosowej

\begin{tabular}{lcccc}
\hline \multicolumn{1}{c}{$\begin{array}{c}\text { Trait } \\
\text { Cecha }\end{array}$} & $\begin{array}{c}\text { Male conditio } \\
\text { Kondycja } \\
\text { samców }\end{array}$ & $\begin{array}{c}\mathrm{N} \\
\text { Total } \\
\text { Ogólnie }\end{array}$ & $\begin{array}{c}\text { Number of males } \\
\text { Liczba samców }\end{array}$ & $\begin{array}{c}\text { Percentage } \\
\text { Procent }\end{array}$ \\
\hline Aggressive behaviours & $\mathrm{I}$ & 50 & 8 & 16.00 \\
Zachowania agresywne & $\mathrm{II}$ & 63 & 10 & 15.87 \\
\hline Total & $\mathrm{III}$ & 48 & 4 & 13.33 \\
Razem & & 161 & 22 & 10.00 \\
\hline Males that failed to mate & $\mathrm{I}$ & 50 & 5 & 6.35 \\
Samce, które nie kryły & $\mathrm{II}$ & 63 & 5 & 10.42 \\
\hline Total & $\mathrm{III}$ & 48 & 14 & 8.70 \\
Razem & & 161 & 1 & 2.00 \\
\hline Fur chewing & $\mathrm{I}$ & 50 & 0 & 0.00 \\
Wygryzienia okrywy włosowej & II & 63 & 2 & 4.17 \\
\hline Total & III & 48 & 3 & 1.86 \\
Razem & & 161 & 5 & \\
\hline
\end{tabular}

\section{DISCUSSION}

Body condition of males did not affect the number of copulations carried out in the entire mating season. Thom et al. (2004) also report that male condition has no effect on the number or copulations but on their duration; larger males took longer to copulate than smaller ones. Díez-León et al. (2013), on the other hand, observed that a low body weight of a male correlated with a lower number of matings in the season. According to Thom et al. (2004), copulation time is important for the subsequent reproduction success, as a male which copulates longer supplies more semen to the female. Consideration should be given to the quality of sperm in mink males in relation to body weight and general condition. Namely, as demonstrated by Hammoud et al. (2008), obese men exhibit poorer quality of the semen, which may also apply to the quality of semen in obese male mink.

Sundqvist et al. (1986) report that up to $20 \%$ American mink males may be barren, which may severely affect reproduction performance of females, evident primarily in reduced litter sizes. For this reason, the reproduction performance of females mated to such males should be analysed, however, in terms of body condition of the females. We did not analyse the 
outcomes of the breeding season which the females attained, as the females had not been grouped by body condition. The literature brings many reports on the effect of body condition in males or females in relation to reproductive performance; however, each and every study deals with the condition of one sex only, which seems insufficient. Therefore, in future research, animals which will be mated will be in the same condition group.

As Hansen et al. (2012) conclude, farm mink have gained in body size due to selection, which was aimed to achieve larger pelts; however, a consequence of this change is the risk of obesity affecting the breeding stock. Males are selected to the breeding stock in November, when their body weight is at the maximum. Until March next year, that is until the mating season, the males should be led to the breeding condition, which provides better reproductive performance. This also applies to females, since reduction in body weight of females in the breeding preparation period increases their reproductive performance (Meagher et al. 2012).

\section{CONCLUSIONS}

The analysis found no effects of body condition of male mink on the number of matings; however, it was found that the condition had an impact on the behaviour of animals during mating. Most aggressive behaviours occurred in thin and ideal condition and about half of such behaviours were observed in the group of obese animals. A completely different relationship was found in fur chewing, as none of thin and ideal condition males exhibited this behaviour. Only very thin males chewed fur. Group II comprised the lowest share of males that failed to mate, about $6 \%$, whereas such males in group I and III represented approximately $10 \%$ each.

\section{REFERENCES}

Andersen N.H. 2013. Effect of stress on reproduction in farmed male mink (Neovison vison) behavioral and hormonal traits characterizing male mink reproductive success. Msc. thesis, Department of Bioscience Aarhus University, http://studerende.au.dk/fileadmin/bioscience/Uddannelse/ Specialerapporter_og_abstracts/2013-05-21_speciale_Nathalia_H_Andersen_.pdf, access: 10.01.2017.

Baekgaard H., Larsen P.F., Sonderup M. 2008. Female body condition and early kit mortality: A description from practice. Scientifur 32(4), 12-18.

Boudreau L. 2012. Effect of moderate diet restriction on body condition, health, and reproductive performance in female mink (Neovison vison). Submitted in partial fulfillment of the requirements for the degree of Master of Science. Nova Scotia, Dalhousie University Halifax.

Boudreau L., Benkel B., Astatkie T., Rouvinen-Watt K. 2014. Ideal body condition improves reproductive performance and influences genetic health in female mink. Anim. Repr. Sci. 145, 86-98.

Canada Mink Breeders Association and the National Farm Animal Care Council. 2013. Code of practice for the care and handling of farmed mink, http://www.canadamink.ca/2013-06_Mink_ _Code_of_Practice.pdf, access: 10.01.2017.

Díez-León M., Bowman J., Bursian S., Filion H., Galicia D., Kanefsky J., Napolitano A., Palme R., Schulte-Hostedde A., Scribner K., Mason G. 2013. Environmentally enriched male mink gain more copulations than stereotypic, barren-reared competitors. Plos One 8(11), 1-11.

Hammoud A., Gibson M., Peterson M., Meikle W., Carrel D. 2008. Impact of male obesity on infertility: a critical review of the current literature. Fertil. Steril. 90(4), 897-904. 
Hansen B.K., Gautason K., Sønderup M., Baekgaard H. 2012. Body condition and reproduction success in farmed mink males (Neovison vison). Scientifur 36(3-4), 63-68.

Meagher R., Bechard A., Palme R., Díez-León M., Hunter D.B., Mason G. 2012. Decreased litter size in inactive female mink (Neovison vison): Mediating variables and implications for overall productivity. Can. J. Anim. Sci. 92, 131-141.

Rouvinen-Watt K., Armstrong D. 2002. Body condition scoring of mink using a five-point scale. Appendix A. Scientifur 28(3), 79-86.

Rouvinen-Watt K. 2003. Nursing sickness in the mink - a metabolic mystery or a familiar foe? The Canadian J. Veter. Res. 67, 161-168.

Schulte-Hostedde A.I., Bowman J., Nituch L.A. 2012. Dynamic spleen mass in wild and domestic American mink. Biol. J. Linn. Soc. 107, 624-631.

Sundqvist C., Toppari J., Parvinen M., Fagerström R., Lukola A. 1986. Elimination of infertile male mink from breeding using sperm test, testicular palpation, testosterone test and fine-needle aspiration biopsy of the testis. Anim. Repr. Sci. 11, 295-305.

Tauson, A.H. 1985. Flushing of mink. Effects of level of flushing on reproductive performance, ovulation rate and plasma progesterone levels in mink. Acta Agric. Scand. 35, 295-309.

Tauson, A.H. 1988. Flushing of mink. Effects of level of preceding feed restriction and length of flushing period on reproductive performance. Anim. Repr. Sci. 17, 243-250.

Thom M.D., Macdonald D.W., Mason G.J., Pedersen V., Johnson P.J. 2004. Female American mink, Mustela vison, mate multiply in a free-choice environment. Anim. Behav. 67, 975-984.

Tinggaard L., Clausen T.N., Larsen P.F. 2012. Investigation of placental scars in mink females. Scientifur 36(3-4), 270-274.

Abstract. The study was aimed to evaluate the relationship between the body condition of males of farmed mink (Neovison vison) and their behaviour as well as mating performance. The observations involved 170 males of Pearl mink. Before the the breeding season, males were assigned to three groups according to their condition: Group I - very thin, Group II - thin and ideal weight, Group III - heavy and obese. On the completion of the mating season, the following reproductive indices were analysed: number of days in mating, number of matings per day and during the entire mating season, fraction of males that failed to mate, incidence of aggressive behaviours. Statistical analysis did not reveal significant differences in the mean number of days in mating, total number of matings or daily number of matings. Male condition score has a significant effect on the behaviour of the animals. The highest rate of aggressive behaviours, $16 \%$, was observed in groups I and II, i.e. in very thin, thin and ideal weight animals. Males of group III, i.e. overweight and obese, showed one half of aggressive behaviours, about $8 \%$. A different pattern was seen in fur chewing, since none of thin or ideal-weight males (Group II) did chew its fur. Only very thin (Group I, $2 \%$ ) and obese males (Group III, 4.17\%) chewed their fur. Group I comprised the lowest fraction of males that failed to mate, about $6 \%$, compared to approx. $10 \%$ in Groups I and III each. 